\title{
Expression and significance of autonomic nerves and $\alpha 9$ nicotinic acetylcholine receptor in colorectal cancer
}

\author{
HUI ZHOU ${ }^{1,2}$, BAOJUN SHI $^{2}$, YITAO JIA ${ }^{3}$, GANG QIU $^{3}$, WEIGUANG YANG ${ }^{1,4}$, JIALI LI ${ }^{5}$, \\ ZHAOLONG ZHAO ${ }^{1}$, JIAN LV ${ }^{1}$, YANNI ZHANG ${ }^{1}$ and ZHONGXIN LI ${ }^{1}$ \\ ${ }^{1}$ Second Department of Surgery, Fourth Hospital of Hebei Medical University, Shijiazhuang, Hebei 050011; \\ ${ }^{2}$ Department of Pediatric Surgery, Second Hospital of Hebei Medical University, Shijiazhuang, Hebei 050000; \\ ${ }^{3}$ Department of Oncology, Hebei General Hospital, Shijiazhuang, Hebei 050051; ${ }^{4}$ Department of Cardiovascular Surgery, \\ Central Hospital of Handan, Handan, Hebei 056001; ${ }^{5}$ Research Center, Fourth Hospital of Hebei Medical University, \\ Shijiazhuang, Hebei 050011, P.R. China
}

Received September 17, 2017; Accepted January 16, 2018

DOI: $10.3892 / \mathrm{mmr} .2018 .8883$

\begin{abstract}
The present study evaluated the distribution of sympathetic and parasympathetic nerves and the expression of the $\alpha 9$ nicotinic acetylcholine receptor $(\alpha 9 \mathrm{nAChR})$ and investigated their potential association with colorectal cancer (CRC) development. The distribution of autonomic nerves and $\alpha 9 \mathrm{nAChR}$ in CRC was detected by immunohistochemistry, which was then used to analyze their association with clinicopathological parameters and prognosis. Sympathetic fibers were primarily observed in the stroma adjacent to cancer cells, whereas parasympathetic fibers were primarily observed in the stroma away from cancer cells. Patients with samples positive for sympathetic nerve fibers had less lymph node invasion and a better prognosis compared with patients with samples negative for sympathetic nerve fibers. The expression of parasympathetic nerves in patients $>60$ years old was increased compared with patients $\leq 60$ years old. The expression of parasympathetic nerves in patients with lymph node invasion was increased compared with patients without lymph node invasion. The detection of parasympathetic nerves gradually increased as CRC (T stage) advanced. Patients with parasympathetic negative samples had better prognoses compared with patients with parasympathetic positive samples. The expression of $\alpha 9 \mathrm{nAChR}$ was principally localized in cellular
\end{abstract}

Correspondence to: Professor Zhongxin Li, Second Department of Surgery, Fourth Hospital of Hebei Medical University, 169 Tianshan Road, Shijiazhuang, Hebei 050011, P.R. China

E-mail: lizhongxin99@163.com

Abbreviations: CRC, colorectal cancer; $\alpha 9 \mathrm{nAChR}, \alpha 9$ nicotinic acetylcholine receptor; Ach, acetylcholine; AChR, acetylcholine receptor; nAChR, $\mathrm{N}$ type cholinergic receptor; TNM, tumor, lymph node, metastasis; TH, Tyrosine hydroxylase; VAChT, vesicular acetylcholine transporter

Key words: colorectal cancer, sympathetic nervous, parasympathetic nervous, $\alpha 9$ nicotinic acetylcholine receptor membranes and the cytoplasm of CRC tissues and it was revealed to have a positive association with the number of parasympathetic nerves. Increased $\alpha 9 \mathrm{nAChR}$ expression was observed in patients $>60$ years old compared with patients $<60$ years old. The detection rate of $\alpha 9 \mathrm{nAChR}$ in tissues from patients with lymph node invasion was increased compared with patients without lymph node invasion. The detection of $\alpha 9$ AChR gradually increased as the CRC stage advanced. The prognoses for patients with $\alpha 9 \mathrm{nAChR}$ negative tissue were improved compared with the prognoses for patients with $\alpha 9$ nAChR positive tissue. Sympathetic nerves were primarily detected in the early phases of CRC and indicated a good prognosis. Parasympathetic nerves and $\alpha 9 \mathrm{nAChR}$ were principally observed in the late phases of cancer and indicated a poor prognosis. The present study revealed that parasympathetic nerves may promote the progression of CRC through $\alpha 9 n A C h R$.

\section{Introduction}

Colorectal cancer (CRC) is the fourth most commonly diagnosed malignant disease worldwide, after lung, stomach and liver cancer (1). It is estimated that CRC ranks as the fourth and fifth most common cause of cancer death among women and men in China. The prevalence of CRC is rapidly increasing owing to changes in people's lifestyle, such as smoking, obesity, and red meat consumption (2). Despite advances in traditional treatments, such as chemotherapy, radiotherapy, targeted therapy and surgery, there has been no significant breakthrough in the overall curative therapy. The five-year survival rate after diagnosis remains less than $60 \%(3,4)$. Like other cancers, CRC exhibits resistance to cell death, the ability of replication, angiogenesis, tissue invasion and metastasis, and immune escape (5). According to a medical view considering Darwinian evolution, the tumor may be a 'new species' in the body that has an increased ability to proliferate and metastasize (6). Tumors may have highly evolved and conserved information transmission systems, so that large numbers of tumor cells can coordinately proliferate, hibernate and metastasize. Steven Paget's theory of 'seed and soil' was considered a milestone in 
tumor research. It proposed that a suitable microenvironment is the primary requirement for malignant cells to survive in other non-primary focal areas and to continue to grow and form metastases (7). In 1971, Folkman et al proposed the concept of 'angiogenesis' in tumors (8). In 2001, Seifert et al proposed a phenomenon similar to angiogenesis, called neurogenesis (9). Subsequent studies confirmed that neurogenesis in bladder, breast, colorectal and pancreatic cancer was closely correlated with tumor progression, as well as prognosis (10-14). Albo et al revealed that neurogenesis was a marker for tumor invasion and prognosis, and the five-year survival rate of patients with neurogenesis was reduced by $50 \%$ compared with those lacking neurogenesis (13). Tumors cells secrete many cytokines, such as nerve growth factor, insulin-like growth factor and brain-derived nerve growth factor, which not only promote neurogenesis within the tumor, but also play an important role in accelerating tumor development $(15,16)$. Moreover, nerve and tumor cells may interact in an autocrine, paracrine or endocrine manner via the neuro-neoplastic synapse (17).

The autonomic nervous system consists of sympathetic and parasympathetic nerves. Magnon et al (18) revealed that in prostate cancer, sympathetic nerves are mainly distributed in normal tissue around the tumor, and parasympathetic nerves are mainly found between the tumor cells. Both types of nerves show complementary progressive effects in tumor occurrence and development. Sympathetic nerves were observed in the early stages of prostate cancer and were associated with occurrence of disease. Parasympathetic nerves were mainly expressed in the late stage, associated with poor progression and metastasis (18). Cutting parasympathetic nerves or local injection of neurotoxic drugs significantly reduced tumor appearance and development, but the effects were limited to regions of innervations (19). Considering this point, parasympathetic nerves were more closely associated with the progression of tumors than the sympathetic nerves. Disrupted cholinergic signals may inhibit Wnt signaling pathways and stem cell proliferation. Blocking or knockdown of the choline M3 receptor inhibited gastric cancer (20). However, to date, the clinical significance of sympathetic and parasympathetic nerves in human CRC has not been reported.

There are multiple neurotransmitter receptors on tumor cells that may affect tumor development (21). Parasympathetic neurotransmission involves acetylcholine (ACh) and two types of cholinergic receptor (acetylcholine receptor, AChR), the toadstool alkali $(\mathrm{M})$ and nicotinic $(\mathrm{N})$ type receptors. The $\mathrm{M}$ type receptor has five subtypes: those found in the central nervous system are M1, M3 and M4, and those in peripheral nerves are M1, M2 and M3. The $\mathrm{N}$ type cholinergic receptor (nAChR) is a pentameric gate control ion channel composed of different subunits $(\alpha 2-\alpha 10, \beta 2-\beta 4)$ (22). Because cancer cells express many kinds of AChR (23-26), cholinergic neurotransmitters or other agonists can affect tumor progression via their corresponding receptors. Currently, $\alpha 7 \mathrm{nAChR}$ is widely studied because it has a role in tumor development, such as pancreatic and lung cancer, by regulating signaling pathways such as PI3K-AKT, NF- $\mathrm{B}$ and STAT (27-29). Another cholinergic receptor, $\alpha 9 \mathrm{nAChR}$, was overexpressed in malignant tumors, especially in breast cancer $(30,31)$, and promoted breast cancer metastasis by activating vimentin and fibronectin $(32,33)$. The expression and significance of $\alpha 9 \mathrm{nAChR}$ in CRC remains unknown. In this study, we examined the expression of autonomic nerves and $\alpha 9 \mathrm{nAChR}$ in $\mathrm{CRC}$ by immunohistochemical methods, and then analyzed their relationship with clinical stages, lymph node metastasis and prognosis.

\section{Materials and methods}

Patients and specimens. During January 2008 to January 2011, tissue samples were collected (by the same surgeon) from 90 patients with CRC at the Second Department of Surgery of the Forth Hospital of Hebei Medical University. All patients were undergoing their first CRC surgery. Before surgery, no patients received radiation or chemotherapy, and all CRC was confirmed by pathology for adenocarcinoma. CRC tissues were stock in the paraffin-embeded form after fixation in formalin and dehydration with increasing-concentration alcohol. Collection and use of specimens were approved with the patients' informed consent and by the ethics committee of the Forth Hospital of Hebei Medical University. Total survival time was defined from diagnosis to time of patient's death or the last follow-up visit. Postoperative TNM stage of CRC followed the 8th Edition of the American Joint Committee on Cancer grading system (34). Tumor, lymph node, metastasis (TNM) system are considered as standardized classification system for evaluating cancer at a population level in terms of the extent of disease, determined by cancer biology and habitual nature as well as predicting cancer outcome and response to treatment.

Histological analysis. Immunohistochemistry detected the expression of autonomic nerves and $\alpha 9 \mathrm{nAChR}$ in a tumor microenvironment. Tyrosine hydroxylase (TH) and vesicular acetylcholine transporter (VAChT) were used as specific markers for sympathetic and parasympathetic nerves, respectively. Tissue samples were fixed in $4 \%$ buffered formaldehyde, decalcified, paraffin-embedded and sectioned to 3-5 $\mu \mathrm{m}$. Paraffin sections were dewaxed, rehydrated and treated for standard antigen retrieval, and incubated with anti-TH antibody (rabbit anti-human monoclonal antibody, ab6211, Massachusetts, USA, 1:500) and anti-VAChT antibody (rabbit anti-human monoclonal antibody, ab68984, Massachusetts, USA, 1:100). An antibody for a9nAChR (rabbit anti-human monoclonal antibody, ab177119, Massachusetts, USA, 1:100) was used to detect expression of $\alpha 9 \mathrm{nAChR}$. Goat anti-rabbit IgG-HRP antibody (Aorui Dongyuan Biotechnology, Wuxi, China) was used as secondary antibody and specific binding detected using DAB (Zhongshan Jinqiao Biotechnology, Beijing, China). An OLYMPUS BX61 universal microscope was used to analyze slide images, with nerve fibers stained brown or yellow designed as positive. For $\alpha 9 \mathrm{nAChR}$ detection, the presence of brown-yellow or brown particles in the cell membrane or in the plasma was defined as a positive image. According to the proportion of positive cells and the staining strength of positive cells, the experimental results of $\alpha 9 \mathrm{nAChR}$ were determined. A: The proportion of positive cells $<1 / 3$ was scored as 1 point; the proportion of positive cells $1 / 3 \sim 2 / 3$ was scored as 2 point; the proportion of positive cells $>2 / 3$ was scored as 3 point. B: According to the staining of the cells, the non-positive cells was scored as 0 point; the light yellow was scored as 1 point; the claybank was scored as 2 point; and the tan was scored as 3 point. The integral is 
Table I. Clinicopathological features and prognosis of 73 patients with colorectal cancer.

\begin{tabular}{|c|c|c|c|c|c|c|}
\hline \multirow[b]{2}{*}{ Characteristic } & \multicolumn{3}{|c|}{ 5-year survival rate } & \multicolumn{3}{|c|}{ OS } \\
\hline & Total no. & Sur no. & Sur R $(\%)$ & HR & $95 \% \mathrm{CI}$ & P-value \\
\hline \multicolumn{7}{|l|}{ Gender } \\
\hline Male & 43 & 34 & -79.10 & 1 & - & - \\
\hline Female & 47 & 37 & -78.70 & 0.968 & $0.393-2.384$ & 0.944 \\
\hline \multicolumn{7}{|l|}{ Location } \\
\hline Rectum & 55 & 43 & -78.20 & 1 & - & - \\
\hline Colon & 35 & 28 & -80.00 & 0.904 & $0.356-2.298$ & 0.833 \\
\hline \multicolumn{7}{|l|}{ T stage } \\
\hline $\mathrm{T} 1$ & 2 & 1 & -50.00 & 1 & - & - \\
\hline $\mathrm{T} 2$ & 20 & 18 & -90.00 & 0.235 & $0.021-2.598$ & 0.238 \\
\hline $\mathrm{T} 3$ & 29 & 22 & -75.90 & 0.641 & $0.057-4.995$ & 0.648 \\
\hline $\mathrm{T} 4$ & 39 & 30 & -76.90 & 0.534 & $0.068-4.218$ & 0.552 \\
\hline \multicolumn{7}{|l|}{$\mathrm{LN}$} \\
\hline$(+)$ & 42 & 29 & -69.00 & 1 & - & - \\
\hline$(-)$ & 48 & 42 & -87.50 & 0.357 & $0.135-0.939$ & $0.037^{\mathrm{a}}$ \\
\hline \multicolumn{7}{|l|}{ TNM } \\
\hline $\mathrm{I}+\mathrm{II}$ & 50 & 45 & -90.00 & 1 & - & - \\
\hline III & 40 & 26 & -65.00 & 4.273 & $1.536-11.888$ & $0.005^{\mathrm{a}}$ \\
\hline \multicolumn{7}{|l|}{ PN } \\
\hline$(+)$ & 45 & 29 & -64.40 & 1 & - & - \\
\hline$(-)$ & 45 & 42 & -93.30 & 0.161 & $0.047-0.554$ & $0.005^{\mathrm{a}}$ \\
\hline \multicolumn{7}{|l|}{$\mathrm{SN}$} \\
\hline$(+)$ & 48 & 42 & -87.50 & 1 & - & - \\
\hline$(-)$ & 42 & 29 & -69.00 & 2.822 & $1.070-7.444$ & $0.036^{\mathrm{a}}$ \\
\hline \multicolumn{7}{|l|}{$\alpha 9$} \\
\hline$(+)$ & 40 & 26 & -56.00 & 1 & - & - \\
\hline$(-)$ & 50 & 45 & -90.00 & 0.228 & $0.082-0.634$ & $0.005^{\mathrm{a}}$ \\
\hline
\end{tabular}

Cox regression analyses were used to analyze survival status. ${ }^{\mathrm{P}}<0.05$. LN, lymph nodes; TNM, tumor, lymph node, metastasis; PN, parasympathetic nerve; SN, sympathetic nerve; $\alpha 9, \alpha 9 \mathrm{nAChR}$; Sur R, survival rate.

equal to $\mathrm{A} \times \mathrm{B} . \mathrm{A} \times \mathrm{B}=0$ was classified as $(-) ; \mathrm{A} \times \mathrm{B}=1 \sim 2$ was classified as (+); $\mathrm{A} \times \mathrm{B}=3 \sim 4$ was classified as $(++) ; \mathrm{A} \times \mathrm{B}=6$ $\sim 9$ was classified as $(+++)$.

Statistical analysis. Relationships between the presence of autonomic nerves or $\alpha 9 \mathrm{nAChR}$ and the clinical pathology were assessed using chi-square and correlation tests. Cox proportional risk regression analysis was used for single variable and multivariate analysis to examine the underlying prognostic factors of overall survival. Cox regression analyses were used to analyze survival status. Survival curve differences were analyzed using the log-rank test. Statistical analysis was done using SPSS22.0 statistical analysis software. Two-side tests were used to compare statistical differences, and $\mathrm{P}<0.05$ was regarded as significant.

\section{Results}

Clinicopathological features and prognosis of patients with $C R C$. The clinicopathologic features and prognosis of patients with CRC in this trial are shown in Table I. A return visit for 90 patients was completed via telephone. Seventy-three cases provided survival data, and 19 cases died before the return visit, all of whom died of postoperative tumor distant metastasis (pulmonary, bone and multiple metastases in 11, 4 and 5 cases, respectively). The overall survival rate was $73.97 \%$. The prognosis was not significantly associated with gender, location and stage of cancer $(\mathrm{P}>0.05)$. The prognosis of lymph node metastatic negative patients was greater than that of lymph node metastasis positive patients $(\mathrm{P}<0.05)$. Considering the few cases of CRC in stage I, we combined the cases in stages I and II, and compared them with stage III cases. Patients with stages I+II CRC had a better prognosis than those with stage III CRC $(\mathrm{P}<0.05)$.

Expression of autonomic nerves and $\alpha 9 n A C h R$ in CRC. Expression of autonomic nerves and $\alpha 9 \mathrm{nAChR}$ in $\mathrm{CRC}$ is shown in Fig. 1. Most of the sympathetic fibers were seen in the stroma adjacent to cancer cells (Fig. 1A). Most of 

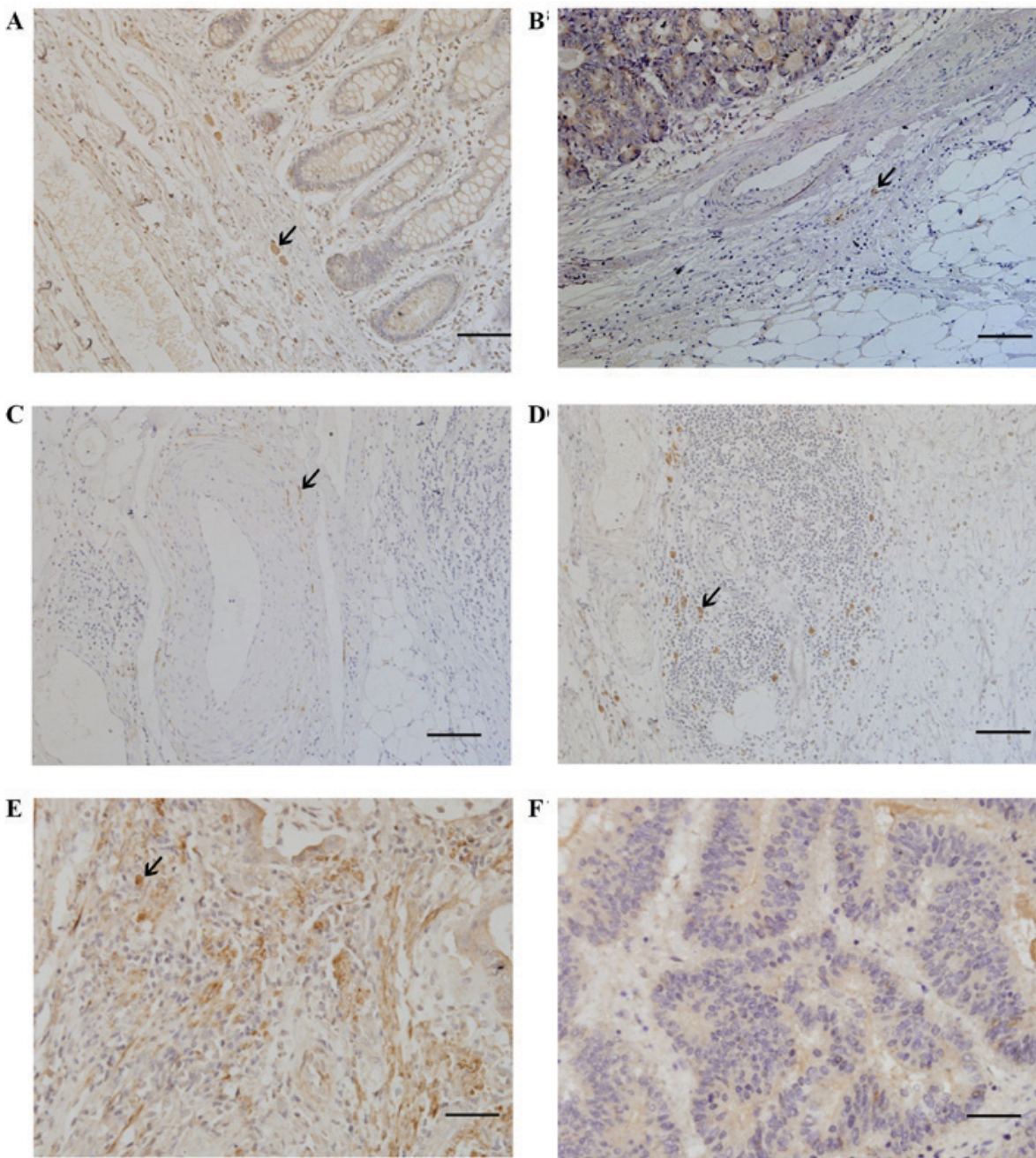

Figure 1. Expression of autonomic nerves and $\alpha 9 \mathrm{nAChR}$ in CRC. (A) Expression of sympathetic fibers in the stroma adjacent to cancer cells. (B) Expression of parasympathetic fibers in the stroma away from cancer cells. (C) Expression of parasympathetic fibers surrounding the blood vessels. (D) Expression of parasympathetic fibers located in tertiary lymphoid tissue. (E) Expression of $\alpha 9 \mathrm{nAChR}$ in CRC tissue. (F) Expression of $\alpha 9 \mathrm{nAChR}$ in normal rectal tissue. Magnification, x400 (scale bar, $20 \mu \mathrm{m}$ ).

the parasympathetic fibers were seen in the stroma away from cancer cells (Fig. 1B). Some parasympathetic fibers surrounded the blood vessels (Fig. 1C) and were sporadically located in tertiary lymphoid tissue (Fig. 1D). The $\alpha 9$ nAChR was expressed in CRC tissues (Fig. 1E), and was not detected in normal rectal tissues (Fig. 1F).

Relationship between autonomic nerves as well as $\alpha 9 n A C h R$ and the survival rate of patients with $C R C$. Relationships between autonomic nerves as well as $\alpha 9 \mathrm{nAChR}$ and the survival rate of patients with CRC are shown in Fig. 2. Comparison of survival rates of patients with CRC showed that patients with sympathetic nerve positive CRC tissue had a better prognosis compared with those having sympathetic nerve negative tissue. There was a significant difference $(\mathrm{P}<0.05)$ between the survival rates of these two groups (Fig. 2A). Patients with parasympathetic nerve positive tissue had a worse prognosis compared with patients that had parasympathetic nerve negative tissue, shown by the significant difference $(\mathrm{P}<0.05)$ between the survival rates of these two groups (Fig. 2B). Patients with $\alpha 9$ nAChR positive CRC tissue had a worse prognosis compared with patients that had $\alpha 9 n A C h R$ negative tissue, shown by the significant difference $(\mathrm{P}<0.05)$ between the survival rates of these two groups (Fig. 2C).

Relationship between autonomic nerves as well as $\alpha 9 n A C h R$ and the clinical pathology of CRC. The relationships between sympathetic nerves and clinical pathological features are shown in Table II. The presence of sympathetic nerves had no significant correlation with age, tumor location, gender, and cancer stages ( $\mathrm{T}$ and TNM criteria). The lymph node invasion rate of patients with sympathetic nerve positive tissue was significantly lower than that of patients with sympathetic nerve negative tissue ( 41.7 vs. $66.7 \%, \mathrm{P}=0.018$ ), suggesting that sympathetic nerves are inversely related to the lymph node invasion.

The relationships between parasympathetic nerves and clinical pathological characteristics are shown in Table III. The presence of parasympathetic nerves was not significantly associated with tumor location and gender $(\mathrm{P}>0.05)$. Patients $>60$ years of age had a higher incidence of parasympathetic nerve expression compared with those $\leq 60$ years of age $(62.5$ vs. $40.0 \%, \mathrm{P}=0.034)$. Patients with lymph node invasion had a higher incidence of parasympathetic nerve expression than those without lymph nodes invasion (62.5 vs. $35.7 \%, \mathrm{P}=0.011)$. 
A
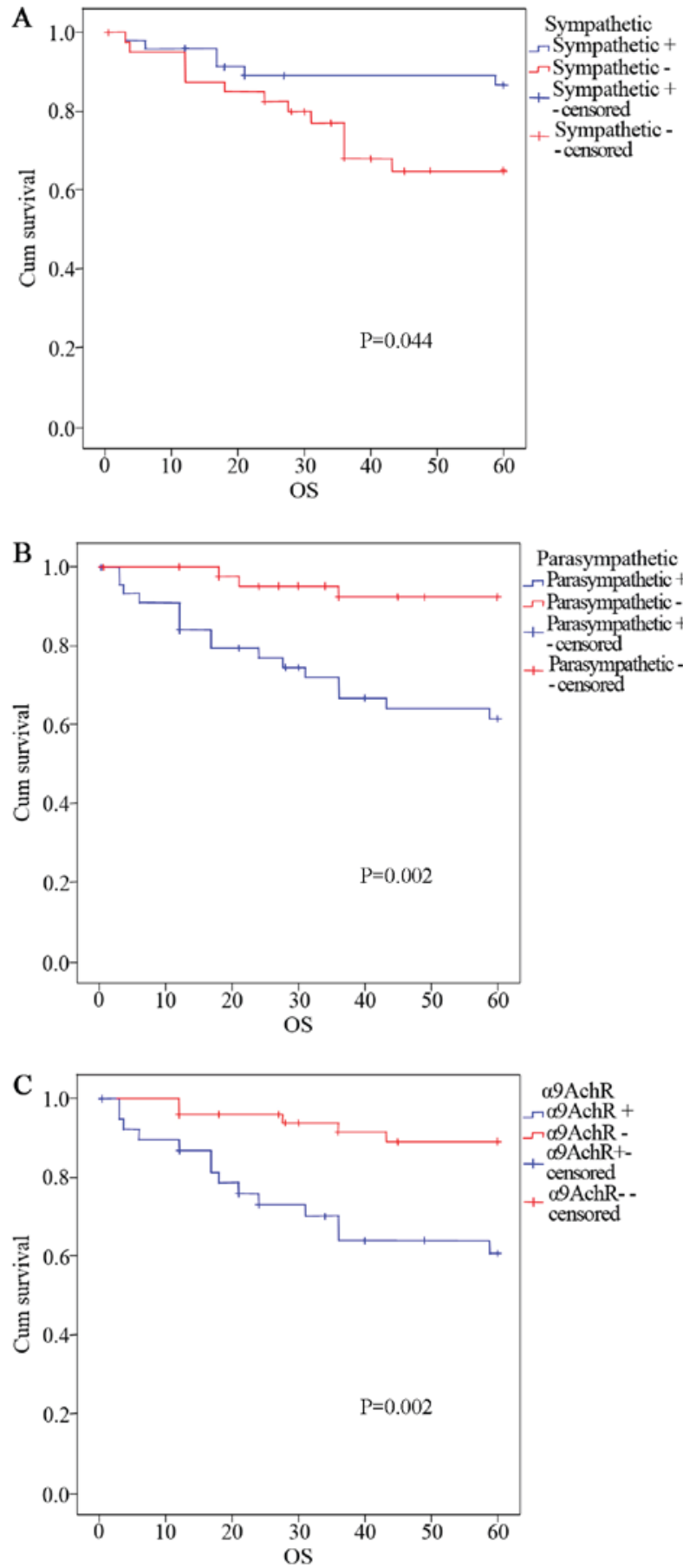

Figure 2. Relationship between autonomic nerves as well as $\alpha 9 \mathrm{nAChR}$ and the survival rates of colorectal cancer patients. (A) Patients with sympathetic nerve positive tissue had a better prognosis than patients with sympathetic nerve negative tissue $(\mathrm{P}=0.044)$. (B) Patients with parasympathetic nerve positive tissue had a worse prognosis than patients with parasympathetic nerve negative tissue $(\mathrm{P}=0.002)$. (C) Patients with $\alpha 9 \mathrm{nAChR}$ positive expression had a worse prognosis than patients with $\alpha 9 \mathrm{nAChR}$ negative expression $(\mathrm{P}=0.002)$.

As the cancer (T stage) advanced, parasympathetic nerve positive rates gradually increased (T1 50.0 T2 25.0 T3 48.3 and T4 $64.1 \%, \mathrm{P}=0.043$ ), suggesting that the presence of parasympathetic nerves was positively correlated with age, lymph node invasion and cancer $\mathrm{T}$ stage.

The relationships between $\alpha 9 \mathrm{nAChR}$ and clinical pathological features are shown in Table IV. The expression of $\alpha 9 \mathrm{nAChR}$ was not associated with gender or tumor location of CRC patients $(\mathrm{P}>0.05)$. The expression of $\alpha 9 \mathrm{nAChR}$ in patients $>60$ years of age was higher than that of patients $\leq 60$ years of age (57.5 vs. $34.0 \%, \mathrm{P}=0.026$ ). The expression of $\alpha 9 \mathrm{nAChR}$ in patients with lymph node invasion was significantly higher than that of patients without lymph nodes invasion (66.7 vs. $42.9 \%, \mathrm{P}=0.023)$. As the cancer T stage advanced, the expression of $\alpha 9 \mathrm{nAChR}$ gradually increased (0 T1, 20.0 T2, 44.8 T3, $59.0 \% \mathrm{~T} 4, \mathrm{P}=0.021$ ), suggesting that $\alpha 9 \mathrm{nAChR}$ expression was positively correlated with age, cancer $\mathrm{T}$ stage and lymph node invasion.

\section{Discussion}

In the present study, we revealed that there are sympathetic and parasympathetic nerves in the human CRC microenvironment. Sympathetic fibers were mainly found in the stroma adjacent to cancer cells. Patients with sympathetic nerves detected in CRC tissue have less lymph node invasion compared with patients exhibiting tissue with no detectable sympathetic nerves. The presence of sympathetic nerves in CRC had no significant correlation with age, tumor location, gender, and cancer ( $\mathrm{T}$ and TNM) stage. The prognosis of patients with sympathetic nerve positive CRC was better than patients with sympathetic negative tissue. Parasympathetic fibers were mainly detected in the stroma away from cancer cells, and some parasympathetic fibers were observed around the blood vessels. The expression of $\alpha 9 \mathrm{nAChR}$ was mainly located in cellular membrane and cytoplasm of CRC tissues. The detection of parasympathetic nerves and $\alpha 9 \mathrm{nAChR}$ was positively related to cancer $\mathrm{T}$ stage, lymph node invasion and age; as expression of parasympathetic nerves and $\alpha 9 \mathrm{nAChR}$ increased in CRC tissue, the prognosis of patients became poor, suggesting that parasympathetic nerves may participate in the late development of tumors via $\alpha 9$ nAChR

Tumors are not an isolated structure, and are associated with the microenvironment of the host tissues (35). Recently, researchers reported that neurogenesis was present in colorectal tumors (36). Our study also revealed that there were sympathetic and parasympathetic nerves in CRC. Parasympathetic nerves were closely associated with the development of tumors. Acetylcholine is a neurotransmitter in parasympathetic nerves, which function via the AChR $(37,38)$. The AChR is also expressed in some non-neuronal cells, such as lung cancer and CRC cells (39). Nicotine, as well as its structural analogues nitrosamines 4-(methylnitrosamino)-1-(3-pyridyl)-1-butanone and N'-nitrosonornicotine, can activate a variety of nAChR subtypes found in the parasympathetic nervous system, resulting in a various biological responses (40). Nicotine can induce the proliferation of a variety of cancer cells, such as small cell lung cancer, non-small cell lung cancer, pancreatic and colon cancer cells, in receptor-dependent manner $(41,42)$. In human bronchial epithelial cells and lung cancer cells, the $\alpha 7 \mathrm{nAChR}$ inhibitors mecamylamine reduced cell proliferation mediated by nicotine (43). Moreover, the nAChR antagonist d-tubocurarine reduced the proliferation of MSTO-211 mesothelioma cells in vitro (44). Another type of AChR was found in mammalian ear vestibular hair cells type II, called $\alpha 9 \mathrm{nAChR}$ (45). The $\alpha 9 \mathrm{nAChR}$ was closely associated with the development of breast cancer $(46,47)$. To date, there have 
Table II. Association between sympathetic nerves and clinical pathological features.

\begin{tabular}{|c|c|c|c|c|c|}
\hline \multirow[b]{2}{*}{ Characteristic/group } & \multicolumn{2}{|c|}{ Sympathetic nerve } & \multirow[b]{2}{*}{$\mathrm{N}$} & \multirow[b]{2}{*}{ Expression rate $(\%)$} & \multirow[b]{2}{*}{ P-value } \\
\hline & - & + & & & \\
\hline Gender & & & & & 0.382 \\
\hline Male & 18 & 25 & 43 & 58.1 & \\
\hline Female & 24 & 23 & 47 & 48.9 & \\
\hline Age & & & & & 0.571 \\
\hline$\leq 60$ & 22 & 28 & 50 & 56.0 & \\
\hline$>60$ & 20 & 20 & 40 & 50.0 & \\
\hline Location & & & & & 0.58 \\
\hline Rectum & 21 & 14 & 35 & 40.0 & \\
\hline Colon & 27 & 28 & 55 & 50.9 & \\
\hline $\mathrm{T}$ & & & & & 0.555 \\
\hline $\mathrm{T} 1$ & 0 & 2 & 2 & 100.0 & \\
\hline $\mathrm{T} 2$ & 9 & 11 & 20 & 55.0 & \\
\hline $\mathrm{T} 3$ & 15 & 14 & 29 & 48.3 & \\
\hline $\mathrm{T} 4$ & 19 & 20 & 39 & 51.3 & \\
\hline $\mathrm{N}$ & & & & & $0.018^{\mathrm{a}}$ \\
\hline No & 14 & 28 & 42 & 66.7 & \\
\hline $\mathrm{N}+$ & 28 & 20 & 48 & 41.7 & \\
\hline
\end{tabular}

Cox proportional risk regression analysis was used for single variable and multivariate analysis to examine the underlying prognostic factors of overall survival. ${ }^{\mathrm{P}} \mathrm{P}<0.05$. $\mathrm{T}$, tumor; $\mathrm{N}$, lymph node.

Table III. Association between parasympathetic nerves and clinical pathological features.

\begin{tabular}{|c|c|c|c|c|c|}
\hline \multirow[b]{2}{*}{ Characteristic/group } & \multicolumn{2}{|c|}{ Sympathetic nerve } & \multirow[b]{2}{*}{$\mathrm{N}$} & \multirow[b]{2}{*}{ Expression rate (\%) } & \multirow[b]{2}{*}{ P-value } \\
\hline & - & + & & & \\
\hline Gender & & & & & 0.291 \\
\hline Male & 19 & 24 & 43 & 55.80 & \\
\hline Female & 26 & 21 & 47 & 44.70 & \\
\hline Age & & & & & $0.034^{\mathrm{a}}$ \\
\hline$\leq 60$ & 30 & 20 & 50 & 40.00 & \\
\hline$>60$ & 15 & 25 & 40 & 62.50 & \\
\hline Location & & & & & 0.052 \\
\hline Rectum & 22 & 13 & 35 & 37.10 & \\
\hline Colon & 23 & 32 & 55 & 58.20 & \\
\hline $\mathrm{T}$ & & & & & $0.043^{\mathrm{a}}$ \\
\hline $\mathrm{T} 1$ & 1 & 1 & 2 & 50.00 & \\
\hline $\mathrm{T} 2$ & 15 & 5 & 20 & 25.00 & \\
\hline $\mathrm{T} 3$ & 15 & 14 & 29 & 48.30 & \\
\hline $\mathrm{T} 4$ & 14 & 25 & 39 & 64.10 & \\
\hline $\mathrm{N}$ & & & & & $0.011^{\mathrm{a}}$ \\
\hline N0 & 27 & 15 & 42 & 35.70 & \\
\hline $\mathrm{N}+$ & 18 & 30 & 48 & 62.50 & \\
\hline
\end{tabular}

Cox proportional risk regression analysis was used for single variable and multivariate analysis to examine the underlying prognostic factors of overall survival. ${ }^{\mathrm{P}}<0.05$. $\mathrm{T}$, tumor; $\mathrm{N}$, lymph node. 
Table IV. Association between $\alpha 9$ nAChR and clinical pathological features.

\begin{tabular}{|c|c|c|c|c|c|}
\hline \multirow[b]{2}{*}{ Characteristic/group } & \multicolumn{2}{|c|}{ A9nachr } & \multirow[b]{2}{*}{$\mathrm{N}$} & \multirow[b]{2}{*}{ Expression rate $(\%)$} & \multirow[b]{2}{*}{ P-value } \\
\hline & - & + & & & \\
\hline Gender & & & & & 0.962 \\
\hline Male & 24 & 19 & 43 & 44.20 & \\
\hline Female & 26 & 21 & 47 & 44.70 & \\
\hline Age & & & & & $0.026^{\mathrm{a}}$ \\
\hline$\leq 60$ & 33 & 17 & 50 & 34.00 & \\
\hline$>60$ & 17 & 23 & 40 & 57.50 & \\
\hline Location & & & & & 0.134 \\
\hline Rectum & 19 & 16 & 35 & 45.70 & \\
\hline Colon & 21 & 34 & 55 & 61.80 & \\
\hline $\mathrm{T}$ & & & & & $0.021^{\mathrm{a}}$ \\
\hline $\mathrm{T} 1$ & 2 & 0 & 2 & 0 & \\
\hline $\mathrm{T} 2$ & 16 & 4 & 20 & 20.00 & \\
\hline $\mathrm{T} 3$ & 16 & 13 & 29 & 44.80 & \\
\hline $\mathrm{T} 4$ & 16 & 23 & 39 & 59.00 & \\
\hline $\mathrm{N}$ & & & & & $0.023^{\mathrm{a}}$ \\
\hline No & 24 & 18 & 42 & 42.90 & \\
\hline $\mathrm{N}+$ & 16 & 32 & 48 & 66.70 & \\
\hline
\end{tabular}

Cox proportional risk regression analysis was used for single variable and multivariate analysis to examine the underlying prognostic factors of overall survival. ${ }^{\mathrm{P}}<0.05$. $\mathrm{T}$, tumor; $\mathrm{N}$, lymph node.

been no reports regarding the role of $\alpha 9 \mathrm{nAChR}$ in $\mathrm{CRC}$. In the current study, $\alpha 9 \mathrm{nAChR}$ was mainly expressed in the cellular cytoplasm and membranes of CRC tissue, and was not detected in normal colorectal tissues and tumor stroma, which suggested that $\alpha 9 \mathrm{nAChR}$ may not be essential for normal neurotransmitter signaling. We propose that $\alpha 9 n A C h R$ may be induced by some factors found in the tumor, and then plays a role in promoting tumor development by downstream signaling events.

In addition, we found that parasympathetic nerve fibers also exist in tumor tertiary lymphoid tissue, which suggested that parasympathetic nerves are closely associated with immune cells. Immune cells, such as T and B cells, and monocytes, express all five kinds of toadstool alkali AChR (mAChR M1-M5) and different types of nAChR, such as $\alpha 3$, $\alpha 5, \alpha 7, \alpha 9$ and $\alpha 10$, which provide the structural basis for parasympathetic nerves to regulate the immune system (48) Borovikova et al (49) proposed the concept of the 'cholinergic anti-inflammatory pathway', in which ACh released by parasympathetic nerves acted upon $\alpha 7 \mathrm{nAChR}$ in macrophages, which inhibited immune function by suppressing a variety of inflammatory factors (such as TNF- $\alpha$, IL-1 $\beta$, IL-6 and high mobility group protein $(49,50)$. The electrical stimulation of parasympathetic nerves or $\alpha 7 \mathrm{nAChR}$-specific agonists both reduced local or systemic inflammatory responses (51). These findings have been applied to the study of Alzheimer's disease (52), rheumatoid arthritis (53), and endotoxin blood disease (54). Furthermore, nicotine increased the expression of phosphorylated STAT5 by activating $\alpha 7 \mathrm{nAChR}$ on regulatory
T cells, ultimately resulting in elevated activity of regulatory $\mathrm{T}$ cells, which restrained $\mathrm{T}$ cell immunosuppression (55). Therefore, parasympathetic nerves may directly act on tumor cells, as well as inhibit immune cells in the tumor microenvironment, with combined AChR receptor responses promoting tumor progression. The current study may ultimately provide a new avenue for the treatment of CRC.

We found that the expression of parasympathetic nerves in CRC was positively related to the age of the patient. It is well known that the prevalence of both cancer and Alzheimer's disease increases gradually with age (56). Musicco et al reported that cancer rates in patients with Alzheimer's disease were reduced by $50 \%$ compared with normal people of the same age. However, the rates of Alzheimer's disease in cancer patients were reduced by $35 \%$ compared with healthy people of the same age (57). Another epidemiological study showed a reduction of malignant tumor risk was associated with Alzheimer's disease, and the risk of malignant tumors was further reduced using stringent criteria for the diagnosis of dementia (58), which excluded the point that the incidence of malignant tumors affected cognitive impairment. Elderly cognitive impairment may involve chronic inflammation, together with reduced excitability of parasympathetic nerves or the reduction of ACh synthesis and release. The tumor is usually associated with abnormal activation of parasympathetic nerves, which may inhibit immune and inflammatory responses and promote tumor progression. Hence, parasympathetic nerves may provide a 'bridge' connecting cognitive disorders with tumors. Ongoing investigations into the use of 
parasympathetic treatments for these two diseases will have to consider the complications that may arise from multiple AChR actions. Regulating the excitability of parasympathetic nerves to maintain an 'appropriate' state is likely to be an important subject of geriatric medicine in the future.

In conclusion, sympathetic and parasympathetic nerves were found in human CRC. Sympathetic nerves were mostly detected in early phases of cancer associated with good prognosis, whereas parasympathetic nerves and $\alpha 9 \mathrm{nAChR}$ were mostly observed in late phases of cancer associated with bad prognosis. The expression of parasympathetic nerves and $\alpha 9$ nAChR were positively correlated. These results suggest that parasympathetic nerves may promote the progression of CRC through $\alpha 9 \mathrm{nAChR}$. The exact role and mechanism of autonomic nervous system actions in CRC deserve further study.

\section{Acknowledgements}

The present study was supported by The Program of Clinical Excellent Talents of Hebei Province.

\section{References}

1. Siegel R, Desantis C and Jemal A: Colorectal cancer statistics, 2014. CA Cancer J Clin 64: 104-117, 2014.

2. Edwards BK, Ward E, Kohler BA, Eheman C, Zauber AG, Anderson RN, Jemal A, Schymura MJ, Lansdorp-Vogelaar I, Seeff LC, et al: Annual report to the nation on the status of cancer, 1975-2006, featuring colorectal cancer trends and impact of interventions (risk factors, screening, and treatment) to reduce future rates. Cancer 116: 544-573, 2010.

3. Feng B, Sun J, Ling TL, Lu AG, Wang ML, Chen XY, Ma JJ, Li JW, Zang L, Han DP and Zheng MH: Laparoscopic complete mesocolic excision (CME) with medial access for right-hemi colon cancer: Feasibility and technical strategies. Surg Endose 26: 3669-3675, 2012.

4. Sun J1, Jiang T, Qiu Z, Cen G, Cao J, Huang K, Pu Y, Liang H, Huang R and Chen S: Short-term and medium-term clinical outcomes of laparoscopic-assisted and open surgery for colorectal cancer: A single center retrospective case-control study. BMC Gastroenterol 11: 85, 2011.

5. Hanahan D and Weinberg RA: Hallmarks of cancer: The next generation. Cell 144: 646-674, 2011.

6. Pienta KJ, McGregor N, Axelrod R and Axelrod DE: ecological therapy for cancer: Defining tumors using an ecosystem paradigm suggests new opportunities for novel cancer treatments. Transl Oncol 1: 158-164, 2008.

7. Li Q: Circulating tumor cells: Determining its number and what it means. Cytometry A 77: 211-212, 2010.

8. Folkman J, Merler E, Abernathy C and Williams G: Isolation of a tumor factor responsible for angiogenesis. J Exp Med 133: 275-288, 1971.

9. Seifert P and Spitznas M: Tumours may be innervated. Virchows Arch 438: 228-231, 2001.

10. Mitchell BS, Schumacher U and Kaiserling E: Are tumours innervated? Immunohistological investigations using antibodies against the neuronal marker protein gene product 9.5 (PGP 9.5) in benign, malignant and experimental tumours. Tumour Biol 15: 269-274, 1994

11. Seifert P, Benedic M and Effert P: Nerve fibers in tumors of the human urinary bladder. Virchows Arch 440: 291-297, 2002.

12. Kayahara $M$, Nakagawara $H$, Kitagawa $H$ and Ohta $T$ : The nature of neural invasion by pancreatic cancer. Pancreas 35: 218-223, 2007.

13. Albo D, Akay CL, Marshall CL, Wilks JA, Verstovsek G, Liu H, Agarwal N, Berger DH and Ayala GE: Neurogenesis in colorectal cancer is a marker of aggressive tumor behavior and poor outcomes. Cancer 117: 4834-4845, 2011.

14. Lolas G, Bianchi A and Syrigos KN: Tumour-induced neoneurogenesis and perineural tumour growth: A mathematical approach. Sci Rep 6: 20684, 2016.
15. Giger RJ, Hollis ER IId and Tuszynski MH: Guidance molecules in axon regeneration. Cold Spring Harb Perspect Biol 2: a001867, 2010.

16. Mancino M, Ametller E, Gascón P and Almendro V: The neuronal influence on tumor progression. Biochim Biophys Acta 1816: 105-118, 2011.

17. Zänker KS: The neuro-neoplastic synapse: Does it exist? Prog Exp Tumor Res 39: 154-161, 2007.

18. Magnon C, Hall SJ, Lin J, Xue X, Gerber L, Freedland SJ and Frenette PS: Autonomic nerve development contributes to prostate cancer progression. Science 341: 1236361, 2013.

19. Tang J, Li Z, Lu L and Cho CH: $\beta$-Adrenergic system, a backstage manipulator regulating tumour progression and drug target in cancer therapy. Semin Cancer Biol 23: 533-542, 2013.

20. Zhao CM, Hayakawa Y, Kodama Y, Muthupalani S, Westphalen CB, Andersen GT, Flatberg A, Johannessen H, Friedman RA, Renz BW, et al: Denervation suppresses gastric tumorigenesis. Sci Transl Med 6: 250ra115, 2014.

21. Marjolaine PR, Michèle L, Benjamin D, Bruno B and Muriel JS: Role of cholinergic receptors in colorectal cancer: Potential therapeutic implications of vagus nerve stimulation? J Cancer Ther 4: 1116-1131, 2013.

22. Hulme, EC, Birdsall, NJ and Buckley NJ: Muscarinic receptor subtypes. Annu Rev Pharmacol Toxicol 30: 633-673, 1990.

23. Jia Y, Jia Y, Zu S, Zhang Y, Xiao D, Wang D and Ma X: Hypoxia-induced overexpression of alpha5 nicotinic acetylcholine receptor of human lung cancer cell lines. 2014 IEEE Workshop on Electronics, Computer and Applications. IEEE: 969-971, 2014

24. Zhao Q, Yue J, Zhang C, Gu X, Chen $\mathrm{H}$ and Xu L: Inactivation of $\mathrm{M} 2 \mathrm{AChR} / \mathrm{NF}-\kappa \mathrm{B}$ signaling axis reverses epithelial-mesenchymal transition (EMT) and suppresses migration and invasion in non-small cell lung cancer (NSCLC). Oncotarget 6 : 29335-29346, 2015.

25. Grando SA: Connections of nicotine to cancer. Nat Rev Cancer 14: 419-429, 2014.

26. Zhao Y, Zhou W, Xue L, Zhang W and Zhan Q: Nicotine activates YAP1 through nAChRs mediated signaling in esophageal squamous cell cancer (ESCC). PLoS One 9: e90836, 2014.

27. Al-Wadei MH, Al-Wadei HA and Schuller HM: Pancreatic cancer cells and normal pancreatic duct epithelial cells express an autocrine catecholamine loop that is activated by nicotinic acetylcholine receptors alpha3, $\alpha 5$, and $\alpha 7$. Mol Cancer Res 10: 239-249, 2012.

28. Dang N, Meng X and Song H: Nicotinic acetylcholine receptors and cancer. Biomed Rep 4: 515-518, 2016.

29. Yue Y, Liu R, Cheng W, Hu Y, Li J, Pan X, Peng J and Zhang P: GTS-21 attenuates lipopolysaccharide-induced inflammatory cytokine production in vitro by modulating the Akt and NF- $\kappa \mathrm{B}$ signaling pathway through the $\alpha 7$ nicotinic acetylcholine receptor. Int Immunopharmacol 29: 504-512, 2015.

30. Wu C, Hu Z, Yu D, Huang L, Jin G, Liang J, Guo H, Tan W, Zhang M, Qian J, et al: Genetic variants on chromosome $15 \mathrm{q} 25$ associated with lung cancer risk in Chinese populations. Cancer Res 69: 5065-5072, 2009.

31. Changeux JP: Nicotine addiction and nicotinic receptors: Lessons from genetically modified mice. Nat Rev Neurosci 11: 389-401, 2010.

32. Lee CH, Huang CS, Chen CS, Tu SH, Wang YJ, Chang YJ, Tam KW, Wei PL, Cheng TC, Chu JS, et al: Overexpression and activation of the alpha9-nicotinic receptor during tumorigenesis in human breast epithelial cells. J Natl Cancer Inst 102: 1322-1335, 2010 .

33. Tu SH, Lin YC, Huang CC, Yang PS, Chang HW, Chang CH, $\mathrm{Wu} \mathrm{CH}$, Chen LC and Ho YS: Protein phosphatase Mg2+/Mn2+ dependent $1 \mathrm{~F}$ promotes smoking-induced breast cancer by inactivating phosphorylated-p53-induced signals. Oncotarget 7: 77516-77531, 2016.

34. Amin MB, Greene FL, Edge SB, Compton CC, Gershenwald JE, Brookland RK, Meyer L, Gress DM, Byrd DR and Winchester DP: The eighth edition AJCC cancer staging manual: Continuing to build a bridge from a population-based to a more 'personalized' approach to cancer staging. Ca Carcer J Clin 67: 93-99, 2017.

35. Ho YJ, Wang TC, Fan CH and Yeh CK: Current progress in antivascular tumor therapy. Drug Discov Today 22: 1503-1515, 2017.

36. Li M, Yang C, Liu X, Yuan L, Zhang F, Wang M, Miao D, Gu X, Jiang S, Cui B, et al: EphA3 promotes malignant transformation of colorectal epithelial cells by upregulating oncogenic pathways. Cancer Lett 383: 195-203, 2016.

37. $\mathrm{Wu} X$ and Tüzün E: Are linear AChR epitopes the real culprit in ocular myasthenia gravis. Med Hypotheses 99: 26-28, 2017. 
38. Wong HP, Yu L, Lam EK, Tai EK, Wu WK and Cho $\mathrm{CH}$ : Nicotine promotes colon tumor growth and angiogenesis through beta-adrenergic activation. Toxicol Sci 97: 279-287, 2007.

39. $\mathrm{Wu} \mathrm{CH}$, Lee $\mathrm{CH}$ and Ho YS: Nicotinic acetylcholine receptor-based blockade: Applications of molecular targets for cancer therapy. Clin Cancer Res 17: 3533-3541, 2011.

40. Lee $\mathrm{CH}$, Chang YC, Chen CS, Tu SH, Wang YJ, Chen LC, Chang YJ, Wei PL, Chang HW, Chang CH, et al: Crosstalk between nicotine and estrogen-induced estrogen receptor activation induces $\alpha 9$-nicotinic acetylcholine receptor expression in human breast cancer cells. Breast Cancer Res Treat 129: 331-345, 2011.

41. Guertin KA, Gu F, Wacholder S, Freedman ND, Panagiotou OA, Reyes-Guzman $\mathrm{C}$ and Caporaso NE: Time to first morning cigarette and risk of chronic obstructive pulmonary disease: Smokers in the PLCO cancer screening trial. PLoS One 10: e0125973, 2015.

42. Luberto CM, Hyland KA, Streck JM, Temel B and Park ER: Stigmatic and sympathetic attitudes toward cancer patients who smoke: A qualitative analysis of an online discussion board forum. Nicotine Tob Res 18: 2194-2201, 2016.

43. Nuutinen S, Panula P and Salminen O: Different hypothalamic nicotinic $\alpha 7$ receptor expression and response to low nicotine dose in alcohol-preferring and alcohol-avoiding rats. Alcohol Clin Exp Res 40: 329-334, 2016.

44. Cesario A, Russo P, Nastrucci C and Granone P: Is $\alpha 7-n A C h R$ a possible target for lung cancer and malignant pleural mesothelioma treatment. Curr Drug Targets 13: 688-694, 2012.

45. Holt JC, Lioudyno M, Athas G, Garcia MM, Perin P and Guth PS The effect of proteolytic enzymes on the alpha9-nicotinic receptor-mediated response in isolated frog vestibular hair cells. Hear Res 152: 25-42, 2001.

46. Guha P, Bandyopadhyaya G, Polumuri SK, Chumsri S, Gade P, Kalvakolanu DV and Ahmed H: Nicotine promotes apoptosis resistance of breast cancer cells and enrichment of side population cells with cancer stem cell-like properties via a signaling cascade involving galectin-3, $\alpha 9$ nicotinic acetylcholine receptor and STAT3. Breast Cancer Res Treat 145: 5-22, 2014.

47. Zhou T, Wang Y, Guo CK, Zhang WJ, Yu H, Zhang $\mathrm{K}$ and Kong WJ: Two distinct channels mediated by $\mathrm{m} 2 \mathrm{mAChR}$ and $\alpha 9 n A C h R$ co-exist in type II vestibular hair cells of guinea pig. Int J Mol Sci 14: 8818-8831, 2013.

48. Kawashima K, Fujii T, Moriwaki Y and Misawa H: Critical roles of acetylcholine and the muscarinic and nicotinic acetylcholine receptors in the regulation of immune function. Life Sci 91 $1027-1032,2012$
49. Borovikova LV, Ivanova S, Zhang M, Yang H, Botchkina GI, Watkins LR, Wang H, Abumrad N, Eaton JW and Tracey KJ: Vagus nerve stimulation attenuates the systemic inflammatory response to endotoxin. Nature 405: 458-462, 2000.

50. Bencherif M, Lippiello PM, Lucas R and Marrero MB: Alpha7 nicotinic receptors as novel therapeutic targets for inflammation-based diseases. Cell Mol Life Sci 68: 931-949, 2011.

51. Zhang R, Wugeti N, Sun J, Yan H, Guo Y, Zhang L, Ma M, Guo X, Jiao C, Xu W, et al: Effects of vagus nerve stimulation via cholinergic anti-inflammatory pathway activation on myocardial ischemia/reperfusion injury in canine. Int J Clin Exp Med 7: 2615-2623, 2014

52. Vicens P, Ribes D, Heredia L, Torrente M and Domingo JL: Motor and anxiety effects of PNU-282987, an alpha7 nicotinic receptor agonist, and stress in an animal model of Alzheimer's disease. Curr Alzheimer Res 10: 516-523, 2013

53. Koopman FA, Schuurman PR, Vervoordeldonk MJ and Tak PP: Vagus nerve stimulation: A new bioelectronics approach to treat rheumatoid arthritis? Best Pract Res Clin Rheumatol 28: 625-635, 2014.

54. Mazloom R, Eftekhari G, Rahimi-Balaei M, Khori V, Hajizadeh S, Dehpour AR and Mani AR: Correction: The role of $\alpha 7$ nicotinic acetylcholine receptor in modulation of heart rate dynamics in endotoxemic rats. PLoS One 10: e0127826, 2015.

55. Marrero MB and Bencherif M: Convergence of alpha 7 nicotinic acetylcholine receptor-activated pathways for anti-apoptosis and anti-inflammation: Central role for JAK2 activation of STAT3 and NF-kappaB. Brain Res 1256: 1-7, 2009.

56. Daianu M,Jahanshad N,NirTM,Toga AW,Jack CR Jr, Weiner MW and Thompson PM; Alzheimer's DiseaseNeuroimaging Initiative: Breakdown of brain connectivity between normal aging and Alzheimer's disease: A structural k-core network analysis. Brain Connect 3: 407-422, 2013.

57. Musicco M, Adorni F, Di Santo S, Prinelli F, Pettenati C, Caltagirone C, Palmer K and Russo A: Inverse occurrence of cancer and Alzheimer disease: A population-based incidence study. Neurology 81: 322-328, 2013.

58. Roe CM, Fitzpatrick AL, Xiong C, Sieh W, Kuller L, Miller JP, Williams MM, Kopan R, Behrens MI and Morris JC: Cancer linked to Alzheimer disease but not vascular dementia. Neurology 74: 106-112, 2010. 